\title{
Identificação de híbridos de citros resistentes à mancha-marrom-de-alternária por meio de fAFLP e testes de patogenicidade
}

\begin{abstract}
Edvan Alves Chagas ${ }^{(1)}$, Jairo Osvaldo Cazetta(2), Eliana Gertrudes Macedo Lemos ${ }^{(2)}$, Moacir Pasqual(3), Antonio de Goes ${ }^{(2)}$, Jose Darlan Ramos ${ }^{(3)}$, Rafael Pio( ${ }^{(4)}$, Wilson Barbosa ${ }^{(5)}$, Vander Mendonça ${ }^{(6)}$ e Luis Alberto Ambrosio ${ }^{(7)}$

(1)Instituto Agronômico de Campinas (IAC), Centro Avançado de Pesquisa Tecnológica do Agronegócio das Frutas, Av. Luis Pereira dos Santos, o 1.500, CEP 13214-820 Jundiaí, SP. E-mail: echagas@iac.sp.gov.br (2)Universidade Estadual Paulista, Fac. de Ciências Agrárias e Veterinárias, Via de Acesso Prof. Paulo Donato Castellane, s/no, CEP 14884-900 Jaboticabal, SP. E-mail: cazetta@fcav.unesp.br, egerle@fcav.unesp.br, agoes@fcav.unesp.br (3)Universidade Federal de Lavras, Dep. de Agricultura, Caixa Postal 37, CEP 37200-000 Lavras, MG. E-mail: pasqual@ufla.br, darlan@ufla.br (4)Universidade Estadual do Oeste do Paraná, Centro de Ciências Agrárias, Rua Pernambuco, no 1.777, Centro, Caixa Postal 1.008, CEP 85960-000 Marechal Cândido Rondon, PR. E-mail: rafaelpio@hotmail.com (5)IAC, Centro Experimental Central, Av. Theodureto de Almeida de Camargo, no 1.500, CEP 13001-970 Campinas, SP. E-mail: wbarbosa@iac.sp.gov.br (6)Universidade Federal Rural do SemiÁrido, Rod. BR 110, Km 47, Bairro Pres. Costa e Silva, CEP 59625-900 Mossoró, RN. E-mail: vander@ufersa.edu.br (7) Centro APTABovino de Leite, Instituto de Zootecnia, Rua Heitor Penteado, no 56, CEP 13460-000 Nova Odessa, SP. E-mail: ambrosio@iz.sp.gov.br
\end{abstract}

Resumo - O objetivo deste trabalho foi identificar híbridos, oriundos de hibridações controladas entre 'Folha Murcha' x 'Ponkan' e testá-los quanto à resistência a Alternaria alternata f. sp. citri. As plântulas foram obtidas via cultura in vitro de embriões. Utilizou-se o marcador molecular fAFLP para identificação dos híbridos e, em seguida, realizou-se o teste de patogenicidade nos híbridos com isolados de Alternaria alternata f. sp. citri, em condições de laboratório. Os pares de primers EcoRI AAG - MseI CAG e EcoRI ACC-MseI CAA foram os mais eficientes na identificação dos híbridos, os quais identificaram 48,5\% de híbridos. Os híbridos F64, F108, F111, F113, F131 e F139 são potencialmente resistentes a Alternaria alternata f. sp. citri.

Termos para indexação: Citrus sinensis, Citrus reticulata, melhoramento genético, biotecnologia vegetal, marcador molecular.

\section{Alternaria brown spot resistant citrus hybrid identification by means of fAFLP and pathogenicity tests}

\begin{abstract}
The objective of this work was to identify hybrids obtained from controlled crossings between 'Folha Murcha' x 'Ponkan', and to check their resistance to Alternaria alternata f. sp. citri. The seedlings were obtained by in vitro embryo culture. The fAFLP marker technique was used to identify the hybrids, then laboratory pathogenicity test of the hybrids was accomplished with Alternaria alternata f. sp. citri isolates. The pairs of primers EcoRI AAG - Msel CAG and EcoRI ACC - Msel CAA were the most efficient for hybrids identification, and distinguished $48.5 \%$ of hybrids. Hybrids F64, F108, F111, F113, F131 and F139 showed potential resistance to the Alternaria alternata f. sp. citri.
\end{abstract}

Index terms: Citrus sinensis, Citrus reticulata, genetic improvement, plant biotechnology, molecular markers.

\section{Introdução}

A mancha-marrom-de-alternária ou mancha-dealternária das tangerineiras foi constatada pela primeira vez no Brasil em 2001 (Peres et al., 2003). Segundo Informativo do Centro de Citricultura (Centro..., 2003), os sintomas observados em pomares no Brasil são semelhantes aos descritos para "alternaria-brown-spot-of-mandarins" ou "alternaria-brown-spot-of-Minneola-tangelo" em pomares da
África do Sul, Austrália, Espanha, Israel, Turquia e Estados Unidos e Itália (Herrera-Isla, 1992; Vicente et al., 1999; Timmer et al., 2000; Bella et al., 2001; Peres et al., 2003).

Estudos realizados na Clínica de Fitopatologia de Citros do Centro Avançado de Pesquisa Tecnológica do Agronegócio de Citros Sylvio Moreira, do Instituto Agronômico, confirmaram o agente causal da manchamarrom-de-alternária como sendo Alternaria alternata f. sp. citri, e os testes de patogenicidade mostraram a 
susceptibilidade das tangerineiras e seus híbridos. As laranjeiras-doces 'Pêra', 'Limeira Ácida Tahiti', por sua vez, mostraram-se resistentes à doença (Centro..., 2003). Desta forma, considerou-se a possibilidade da utilização de genótipos dessas variedades como parentais em programas de melhoramento genético visando à obtenção de híbridos resistentes à Alternaria alternata f. sp. citri.

Em razão das várias doenças que acometem a citricultura, a busca por novas variedades é o objetivo dos inúmeros programas de melhoramento genético em todo o mundo. Muitas alternativas podem ser utilizadas para se chegar à variabilidade genética, entre as quais o melhoramento genético através de hibridações. Entretanto, os métodos de melhoramento clássicos utilizados no desenvolvimento de novas variedades de citros são limitados por problemas tais como apomixia e embriogenia nucelar, altas taxas de heterozigose, incompatibilidade sexual, esterilidade masculina e feminina, além de longo período juvenil (Soost \& Cameron, 1975). Soma-se a isto a dificuldade para a distinção precoce de plântulas, resultantes da multiplicação somática dos nucelos, e a dificuldade no resgate do embrião zigótico, bem como a ausência de caracteres morfológicos que possibilitem a sua distinção entre ambos os tipos de embriões.

Desta forma, devem-se usar métodos de seleção precoce de progênies no melhoramento genético de citros, que reduzam o tempo e a mão-de-obra na identificação de híbridos. São exemplos desses métodos de seleção: o cultivo in vitro de embriões e a identificação de genótipos por meio de marcadores moleculares fAFLP ("fluorescent Amplified Fragment Lenght Polimorphism").

O marcador molecular AFLP é uma técnica recente desenvolvida por Zabeau (1993), e é intermediária entre as técnicas de RFLP e PCR (Vos et al., 1995). O marcador AFLP analisa a presença ou ausência de sítios de enzimas de restrição e as sequiências polimórficas adjacentes a esses sítios. De acordo com Vos et al. (1995), o AFLP apresenta as seguintes vantagens: maior número de loci pode ser analisado por experimento; número aproximadamente dez vezes maior de marcas informativas pode ser obtido por análise; a técnica gera mais informações do que outros marcadores dominantes como RAPD; o AFLP gera padrões de bandeamento altamente reprodutíveis, devido ao pareamento altamente específico dos primers aos nucleotídeos adaptadores complementares.
O objetivo deste trabalho foi identificar híbridos de citros oriundos de hibridações entre 'Folha Murcha' x 'Ponkan' por meio de marcador molecular fAFLP e testá-los quanto a resistência à mancha-marrom-de-alternária com a utilização de testes de patogenicidade.

\section{Material e Métodos}

As plantas foram obtidas a partir de cruzamentos artificiais controlados entre 'Folha Murcha' (Citrus sinensis, fonte de resistência) x 'Ponkan' (Citrus reticulata, material suscetível), pertencentes à coleção de cítricos do Setor de Fruticultura da Universidade Federal de Lavras, Lavras, MG.

Foram coletados botões florais das variedades de laranjeiras Folha Murcha (genitor masculino) no estádio balão. Em seguida, as anteras foram extraídas com auxílio de uma pinça e colocadas em placas de Petri, forradas com papel-filtro, e armazenadas em sala de crescimento com aproximadamente $25^{\circ} \mathrm{C}, 70 \%$ de umidade relativa do ar, fotoperíodo de 16 horas e irradiância de $32 \mu \mathrm{mol} \mathrm{m} \mathrm{m} \mathrm{s}^{-1}$ por aproximadamente 24 a 48 horas para ocorrer a antese. Posteriormente, com auxílio de uma pinça, as inflorescências da genitora 'Ponkan', que também se encontravam no estádio balão, foram emasculadas e, em seguida, utilizando-se um pincel fino, foram polinizadas. Imediatamente após a polinização, cada flor foi protegida com saco de papel e etiquetada, deixando-se apenas uma flor por ramo, eliminando-se as demais. Aproximadamente 118 dias após a polinização, os frutos foram coletados e armazenados em refrigerador a $5 \pm 1^{\circ} \mathrm{C}$.

Para resgate e cultivo dos embriões, as sementes foram removidas dos frutos provenientes dos cruzamentos realizados na etapa anterior e tratadas com álcool a $70 \%$ por 5 min e, posteriormente, desinfestadas com hipoclorito de sódio (2\%) por 20 min. Em seguida foram lavadas três vezes com água destilada e autoclavada. Posteriormente, em câmara de fluxo laminar e com auxílio de microscópio estereoscópico, bisturi e pinça, realizou-se um corte na região oposta à micrópila para expor os embriões. Estes foram individualizados e inoculados em $15 \mathrm{~mL}$ do meio de cultura MT (Murashige \& Tucker, 1969) vertidos em tubos de ensaio (25x150 mm). Em seguida, os tubos de ensaio foram colocados em sala de crescimento a $27 \pm 1^{\circ} \mathrm{C}$, com $70 \%$ de umidade relativa do ar, fotoperíodo de 16 horas e irradiância de $32 \mu \mathrm{mol} \mathrm{m}{ }^{-2} \mathrm{~s}^{-1}$. Aos 90 dias, as plântulas foram retiradas dos tubos de ensaio, 
transplantadas em células de isopor contendo vermiculita e mantidas em casa de vegetação, com temperatura e umidade controladas. Após a aclimatização, as plântulas foram transferidas para sacos de plástico perfurados para produção de mudas $(28 \times 18 \mathrm{~cm})$, os quais foram preenchidos com uma mistura de terra e areia na proporção de 3:1. A identificação dos híbridos foi conduzida no Dep. de Tecnologia da Faculdade de Ciências Agrárias e Veterinárias da Universidade Estadual Paulista em Jaboticabal, SP.

A extração de DNA genômico dos tecidos vegetais dos genitores e da progênie foi realizada segundo Doyle \& Doyle (1991). Folhas frescas (0,1 g) de cada amostra foram maceradas com nitrogênio líquido e homogeneizadas em tubos de microcentrífuga de $1,5 \mathrm{~mL}$, contendo $750 \mu \mathrm{L}$ de tampão de extração (2\% CTAB, $\mathrm{NaCl} 5 \mathrm{M}, 0,2 \%$ de 2- $\beta$-mercaptoetanol, 0,5 M EDTA, 100 mM TRIS-HClpH 8). Após 60 min de incubação a $65^{\circ} \mathrm{C}$, adicionaramse $450 \mu \mathrm{L}$ de clorofórmio:álcool isoamílico (24:1) e o material foi centrifugado por $15 \mathrm{~min}$ a $17.000 \mathrm{~g}, \mathrm{a} 20^{\circ} \mathrm{C}$, sendo o sobrenadante transferido para um novo tubo, adicionando-se $400 \mu \mathrm{L}$ de isopropanol gelado. Na recuperação do DNA, realizou-se nova centrifugação a $17.000 \mathrm{~g}$ por $15 \mathrm{~min}, \mathrm{a} 0^{\circ} \mathrm{C}$, descartando-se o sobrenadante. Em seguida, o DNA foi "lavado" com uma solução conhecida como "wash buffer" (76\% de etanol e $10 \mathrm{mM}$ de acetato de amônio), e logo depois foi centrifugado a $6.000 \mathrm{~g} \mathrm{a} 0^{\circ} \mathrm{C}$, por $10 \mathrm{~min}$, para obtenção do pellet. Este foi secado em temperatura ambiente, e, em seguida, acrescentado $100 \mu \mathrm{L}$ de TE (10 mM TRIS-HCl, $\mathrm{pH} 7,5$, $1 \mathrm{mM}$ EDTA) e $2 \mu \mathrm{L}$ de RNAse $\left(10 \mu \mathrm{g} \mathrm{mL}^{-1}\right)$. Os tubos foram incubados a $37^{\circ} \mathrm{C}$ por $60 \mathrm{~min}$ e acrescidos de $200 \mu \mathrm{L}$ de água milli-Q, $100 \mu \mathrm{L}$ de acetato de amônia e $1.000 \mu \mathrm{L}$ de etanol absoluto, e mantidos por uma hora no freezer. Em seguida, o material foi centrifugado novamente a $12.000 \mathrm{~g}$ por $10 \mathrm{~min}$, a $0^{\circ} \mathrm{C}$, secado e, posteriormente, ressuspendido em $20 \mu \mathrm{L}$ de TE $(10 \mathrm{mM}$ TRIS-HCl, $\mathrm{pH} 7,5,1 \mathrm{mM}$ EDTA) e armazenados a $-20^{\circ} \mathrm{C}$.

A quantificação de DNA das amostras foi realizada com auxílio de biofotômetro. Além da concentração de DNA, observou-se a relação entre as absorbâncias 260 e $280 \mathrm{~nm}$ (ácidos nucléicos/proteínas) para verificação da qualidade do DNA. Foi realizada também a verificação da integridade do DNA nas soluções por meio dos testes em gel de agarose $0,8 \%$.

Após a obtenção do material genético dos genitores e da progênie $F_{1}$, estes foram avaliados por meio do marcador molecular fAFLP, segundo o protocolo AFLP Plant Mapping Protocol (Applied Biosystems, 1997). O
DNA genômico foi digerido utilizando-se $500 \mathrm{ng}$ de DNA $(10 \mu \mathrm{L})$, acrescido de $1,25 \mu \mathrm{L}$ de tampão React 1 (500 mM Tris- $\mathrm{HCl} \mathrm{pH} \mathrm{8,} 100 \mathrm{mM} \mathrm{MgCl}_{2}$ ), $5 \mathrm{U}$ de $E c o \mathrm{RI}(0,5 \mu \mathrm{L})$ e $1,5 \mathrm{U}$ de $M s e \mathrm{I}(0,3 \mu \mathrm{L})$. Esta reação foi incubada por 14 horas a $37^{\circ} \mathrm{C}$, e, em seguida, as enzimas foram inativadas por $10 \mathrm{~min}, \mathrm{a} 65^{\circ} \mathrm{C}$. Quanto à ligação dos adaptadores, retiraram-se 3,67 $\mu \mathrm{L}$ da reação de digestão e acrescentou-se $1 \mu \mathrm{L}$ de tampão T4 DNA ligase, $0,5 \mu \mathrm{L}$ T4 DNA ligase, $0,33 \mu \mathrm{L}$ do adaptador para o corte da $M s e \mathrm{I}$ e $0,33 \mu \mathrm{L}$ do adaptador para o corte da EcoRI (ambos adaptadores previamente anelados a $95^{\circ} \mathrm{C}$ por $5 \mathrm{~min}$ ). A ligação ocorreu por duas horas a $20^{\circ} \mathrm{C}$ e, posteriormente, foi diluída 7,7 vezes em água destilada. Na amplificação pré-seletiva, retiraram-se $2 \mu \mathrm{L}$ da reação diluída, preparada a partir das reações de digestão e ligação dos adaptadores, acrescentou-se $1 \mu \mathrm{L}$ da mistura dos primers pré-seletivos AFLP EcoRI e $M s e \mathrm{I}$ e $15 \mu \mathrm{L}$ de AFLP Core mix. As amostras foram colocadas no termociclador PTC-100 da MJ Research, Inc. Inicialmente foram submetidas a $72^{\circ} \mathrm{C}$ por $2 \mathrm{~min}$, em seguida, 20 ciclos de $94^{\circ} \mathrm{C}$, por $20 \mathrm{~s}, 56^{\circ} \mathrm{C}$ por $30 \mathrm{~s} \mathrm{e}$ $72^{\circ} \mathrm{C}$ por 2 min e, finalmente, permanecendo a $60^{\circ} \mathrm{C}$ por $30 \mathrm{~min}$.

Após a verificação da reação pré-seletiva em gel de agarose $1 \%$, os produtos amplificados na reação préseletiva foram diluídos duas vezes. Na amplificação seletiva, retiraram-se $1,5 \mu \mathrm{L}$ da reação de amplificação pré-seletiva diluída e acrescentaram-se 7,5 $\mu \mathrm{L}$ do AFLP Core mix, $0,5 \mu \mathrm{L}$ do primer-AXX da EcoRI marcado por fluorescência e $0,5 \mu \mathrm{L}$ do primer-CXX da $M s e I$, sendo ' $\mathrm{XX}$ ' qualquer das combinações de deoxinucleotídeos disponíveis na seqüência dos primers do Kit. Após o preparo das reações, as amostras foram colocadas no termociclador PTC-100 da MJ Research, Inc. Inicialmente foram submetidas à temperatura de $94^{\circ} \mathrm{C}$ por $2 \mathrm{~min}$, seguido por sucessivos ciclos de $94^{\circ} \mathrm{C}$, por $20 \mathrm{~s}$, $66^{\circ} \mathrm{C}$ por 30 s e $72^{\circ} \mathrm{C}$ por 2 min. Em cada ciclo, baixavase um grau na fase de $30 \mathrm{~s}$ até atingir $56^{\circ} \mathrm{C}$ por $30 \mathrm{~s}$. Nesta penúltima etapa, no termociclador, as amostras foram submetidas por 21 vezes ao ciclo de $94^{\circ} \mathrm{C}$ por $20 \mathrm{~s}$, seguidos de $56^{\circ} \mathrm{C}$ por 30 s e $72^{\circ} \mathrm{C}$ por 2 min. Finalmente, foram submetidas ao ciclo de $60^{\circ} \mathrm{C}$ por $30 \mathrm{~min}$.

Na eletroforese, realizada no seqüenciador ABI PRISM 377 , preparou-se uma solução contendo $1,5 \mu \mathrm{L}$ de formamida deionizada, $0,9 \mu \mathrm{L}$ de blue dextran e $0,3 \mu \mathrm{L}$ do padrão interno de peso molecular GeneScan-500 ROX (Applied Biosystems) marcado por fluorescência com a coloração vermelha. Adicionou-se à reação seletiva 1,6 $\mu \mathrm{L}$ desta solução e a reação foi desnaturada no termociclador, 
a $95^{\circ} \mathrm{C}$ por $5 \mathrm{~min}$. Foi aplicado $1,5 \mu \mathrm{L}$ de cada amostra em gel de poliacrilamida a 5\% (Longer-Ranger) com $36 \mathrm{~cm}$ de comprimento, e a eletroforese foi desenvolvida durante quatro horas, a 2.500 volts, usando TEB $1 \mathrm{X}$ (10,8 g TRIS; 5,5 g ácido bórico; 0,83 g de sódio EDTA dihidratado; diluído em $1 \mathrm{~L}$ de água).

O padrão interno de peso molecular Gene Scan-500 ROX, usado no fAFLP, possui 15 fragmentos com os seguintes comprimentos em pares de bases (pb): 50, 75, 100, 139, $150,160,200,250,300,340,350,400,450,490$ e 500 .

A fim de selecionar as melhores combinações de primers, que identificassem loci fAFLPs polimórficos entre os parentais, para posterior utilização na identificação de híbridos $F_{1}$ entre os mesmos, foram testados 21 pares de primers EcoRI-MseI entre 'Ponkan' e 'Folha Murcha' (ACA-CAC, ACA-CAG, ACA-CTT, ACA-CTG, AAG-CAC, AAG-CAA, AAG-CAG, AAG-CTT, AAG-CTG, AGG-CAA, AGG-CAG, AGG-CTT, AGG-CTG, ACC-CAC, ACC-CAA, ACC-CAG, ACC-CTT, ACC-CTG, AGC-CAA, AGC-CAG e AGC-CTT).

Após amplificação, utilizou-se o programa "GeneScan Analysis Software" (Applied Biosystems) para obtenção dos dados provenientes do sequienciador. Em seguida, construiu-se uma tabela binária, analisando-se a presença e ausência de cada fragmento, codificada por 1 e 0 , respectivamente, com o auxílio do "Genotyper DNA Fragment Analysis Software" (Applied Biosystems) para diferenciar os parentais entre si e, posteriormente, a progênie $F_{1}$ de plântulas resultantes do cruzamento dirigido entre 'Folha Murcha' e 'Ponkan'. Posteriormente, elaborou-se a matriz de distância com auxílio do programa Paup (Paup 4.0b10). Com a matriz de distância, foi construído o dendrograma, por meio do programa Mega (Kumar et al., 2004), para verificar a certificação dos diferentes grupos (híbridos e nucelares).

Quanto ao teste de patogenicidade da progênie $F_{1}$, utilizou-se suspensão de conídios, cujas culturas foram obtidas em meio de batata-dextrose-ágar (BDA), durante sete dias sob temperatura de $26^{\circ} \mathrm{C}$ e fotoperíodo de 12 horas. $\mathrm{O}$ isolado de Alternaria alternata f. sp. citri foi obtido a partir de folhas de tangor 'Murcott' com sintomas típicos da doença, cuja patogenicidade foi previamente avaliada mediante inoculação em brotações de tangerineira 'Dancy' (C. rericulata). Em tais colônias foram adicionados $10 \mathrm{~mL}$ de água esterilizada e, mediante raspagem com lâmina, removeu-se o micélio, conídios e conidióforos que, posteriormente, foram filtrados em camada dupla de gaze esterilizada. Esta suspensão foi centrifugada duas vezes por $20 \mathrm{~min}$ a $12.000 \mathrm{~g}$, descartando-se o sobrenadante. Após a determinação da concentração de propágulos na suspensão, com auxílio de um microscópio e hematocitômetro, a suspensão foi diluída a $1 \times 10^{4}$ conídios por $\mathrm{mL}$. Uma gota da suspensão conidial foi colocada numa lâmina de microscópio e incubada por 18 horas em câmara úmida, que foi analisada em seguida para confirmação da viabilidade dos conídios.

$\mathrm{O}$ teste de patogenicidade nos híbridos foi realizado em folhas jovens, com aproximadamente oito dias de idade após o início da brotação, que foram destacadas das plantas, higienizadas com água destilada e colocadas em placas de Petri forradas com papel-filtro umedecido. Em seguida, com auxílio de um pulverizador manual, do tipo De Vilbs, as folhas foram pulverizadas com suspensão de conídios, cujo isolado também foi obtido a partir de folhas de tangor 'Murcott', com sintomas típicos da doença, cuja patogenicidade foi previamente avaliada mediante inoculação em brotações de tangerineira 'Dancy'. A testemunha foi pulverizada com água destilada e esterilizada. Posteriormente, as amostras foram incubadas em câmara úmida a $27^{\circ} \mathrm{C}$.

O delineamento utilizado foi inteiramente casualizado com quatro repetições, e cada repetição foi constituída por duas folhas. As avaliações foram realizadas aos quatro, sete e dez dias após a inoculação, baseando-se na presença e ausência de sintomas. A severidade foi avaliada de acordo com a menor ou maior suscetibilidade das folhas ao surgimento do sintoma, conforme a seguinte notação: - ausência de sintoma; + surgimento do sintoma; ++ folha parcialmente tomada por lesões e; +++ folha totalmente tomada por lesões. Após as avaliações, as notações foram transformadas na escala $0,1,2$ e 3 , representando as notações -, +, ++ e +++, respectivamente. Em seguida, os dados foram submetidos ao teste estatístico nãoparamétrico de Friedman, a 5\% de probabilidade, conforme Conagin et al. (2006).

Os parentais foram utilizados como controle negativo e positivo. Após as avaliações, a variedade Folha Murcha não apresentou o sintoma da doença. Ao contrário, a 'Ponkan' apresentou-se altamente suscetível, como era esperado. Em todos os híbridos, também foram utilizadas testemunhas - tratamentos que foram submetidos aos mesmos testes, entretanto não foram inoculados com a suspensão conidial. 


\section{Resultados e Discussão}

Do conjunto de 21 pares de primers AFLP testados para identificação entre 'Folha Murcha' e 'Ponkan', os pares de primer AAG-CAG, AAG-CAA e AAG-CTT (fluorófilo Joe) apresentaram o maior número de fragmentos amplificados e polimórficos. Estes três pares de primers amplificaram um total de 44,40 e 39 fragmentos, sendo destes 17, 10 e 8 loci AFLP polimórficos entre os parentais, respectivamente. Entre os primers marcados com fluorescência Ned, destacamse os pares ACC-CAA, ACC-CTG e AGC-CAA, os quais amplificaram 31, 28 e 25 sendo, entre estes 11,8 e 7 loci AFLP polimórficos entre os parentais, respectivamente. Considerando-se o baixo número de fragmentos polimórficos entre os parentais 'Ponkan' e 'Folha Murcha', os demais 15 pares de primers não se mostraram eficientes na diferenciação (Tabela 1).

Em razão do número de fragmentos amplificados e de loci AFLP polimorfismo detectados entre os parentais, e da qualidade de visualização na imagem do gel, selecionaram-se os pares de primers AAG-CAG (fluorófilo Joe) e ACC-CAA (fluorófilo Ned) para serem utilizados na diferenciação genética de plântulas provenientes de embriões nucelares e zigóticos, os quais geraram 38,63 e 35,48\% de polimorfismo entre os parentais. Os marcadores fAFLP mostraram-se excelentes na diferenciação dos parentais por sua capacidade de gerar grande número de fragmentos polimórficos por par de primer.

Shimada et al. (1998), ao utilizar o marcador AFLP e RAPD na diferenciação de variedades de laranja 'Pêra', verificaram que a técnica AFLP detectou uma quantidade de polimorfismo entre os materiais estudados aproximadamente 20 vezes maior quando comparado com o RAPD. Os autores ainda ressaltaram a superioridade da técnica de fAFLP na reprodutibilidade de fragmentos amplificados e a rapidez de análise devido ao sistema de marcação dos primers com fluorescência. Narváez et al. (2000), ao estudar a eficiência entre as técnicas RAPD e AFLP para identificação genética de clones de Vitis, também citam a eficiência da técnica AFLP após observarem alta reprodutibilidade dos fragmentos amplificados e a maior quantidade de loci polimórficos detectada por reação. Resultados semelhantes também foram encontrados por Guo et al. (2004) que, ao estudar várias técnicas para caracterização molecular e identificação de hibridização entre híbridos somáticos intergenéricos de Citrus, verificaram que a técnica
AFLP foi mais eficiente e conveniente. Esses autores observaram que todos os pares de primers testados foram capazes de identificar a hibridização entre os híbridos. Grande número de bandas foi gerado, e muitas destas bandas são específicas para os genótipos parentais. Conseqüentemente, informações adicionais a respeito da hibridização foram reveladas.

Com relação aos híbridos identificados, foram analisadas 101 plantas e encontrados, 49 híbridos, ou seja, $48,5 \%$. As 53 restantes são clones nucelares. Verificouse o agrupamento da progênie $F_{1}$ oriunda da hibridação entre 'Folha Murcha' x 'Ponkan' em três grupos distintos (Figura 1). O primeiro representado por híbridos que apresentaram distância genética relativamente significativa $(0,15)$, quando comparado ao segundo grupo, cujos valores situaram-se entre 0,0 e 0,05 . Já o terceiro, apresentou máxima similaridade, constituindo-se no grupo de plantas com origem nucelar.

Devido à qualidade da técnica de AFLP, neste trabalho foram encontradas diferenças genéticas

Tabela 1. Pares de primer (EcoRI-MseI) testados para identificação entre 'Ponkan' e 'Folha Murcha' com os respectivos totais de fragmentos amplificados e números de fragmentos polimórficos gerados.

\begin{tabular}{lcc}
\hline Pares de primers & $\begin{array}{c}\text { Total de fragmentos } \\
\text { amplificados }\end{array}$ & $\begin{array}{c}\text { Número de fragmentos } \\
\text { polimórficos }\end{array}$ \\
\hline ACA-CAC & 28 & 12 \\
ACA-CAG & 38 & 7 \\
ACA-CTT & 49 & 9 \\
ACA-CTG & 40 & 11 \\
AAG-CAC & 24 & 6 \\
AAG-CAA & 40 & 10 \\
AAG-CAG & 44 & 17 \\
AAG-CTT & 39 & 8 \\
AAG-CTG & 33 & 6 \\
AGG-CAA & 26 & 5 \\
AGG-CAG & 22 & 6 \\
AGG-CTT & 20 & 7 \\
AGG-CTG & 20 & 5 \\
ACC-CAC & 22 & 5 \\
ACC-CAA & 31 & 11 \\
ACC-CAG & 22 & 3 \\
ACC-CTT & 18 & 2 \\
ACC-CTG & 28 & 8 \\
AGC-CAA & 25 & 7 \\
AGC-CAG & 14 & 5 \\
AGC-CTT & 9 & 3 \\
\hline
\end{tabular}

(1)Todos os pares de primers com inicial ACA são marcados com fluorófilo Fam; todos os pares de primers com inicial AAG e AGG são marcados com fluorófilo Joe; todos os pares de primers com inicial ACC e AGC são marcados com fluorófilo Ned. 
significativamente maiores, quando comparado com outros marcadores moleculares a exemplo do RAPD (Cristofani \& Machado, 1998; Oliveira et al., 2000; Cristofani et al., 2001).

A técnica fAFLP proporcionou a identificação mais exata de embriões zigóticos neste trabalho. Esta técnica, por sua eficiência na detecção de polimorfismo proporciona, com freqüência, melhores resultados na diferenciação de indivíduos, seja de espécies cítricas ou de outras frutíferas. A proporção de embriões zigóticos e nucelares pode variar com as espécies e variedades de citros (Montenegro, 1958), devido à constituição genética dos parentais, vigor dos híbridos, fatores ambientais, estado fisiológico (Cameron \& Frost, 1968) e condições climáticas da época em que as hibridações são realizadas (Mestre et al., 1997). Estes autores observaram variação na porcentagem de plantas zigóticas de Flying Dragon de 23,2\%, em 1992, a 8,4\%, em 1993. Oliveira et al. (2000), trabalhando com marcador RAPD, encontraram em média 38,98 e $27,92 \%$ de embriões zigóticos na identificação de plantas oriundas do cruzamento entre Citrus reticulata $\mathrm{x}$ Citrus sinensis quando cultivados no sistema de placas de Petri/tubetes e canteiro, respectivamente. Em 2001, data de realização das hibridações controladas, as condições climáticas foram favoráveis. O regime de chuvas foi bem distribuído durante o ciclo de produção da cultura e, principalmente, no período de crescimento e desenvolvimento dos frutos. Tais condições, provavelmente, contribuíram para a obtenção do maior número de híbridos.

Com relação aos resultados do teste de patogenicidade dos híbridos identificados na etapa anterior, 37 híbridos oriundos do cruzamento'Ponkan' x 'Folha Murcha' foram avaliados (Tabela 2). Os outros 12 híbridos identificados precocemente, ou seja, ainda no estágio de plântulas, de um total de 49, morreram durante o período de aclimatização.

Quanto aos três períodos de avaliação dos sintomas, o teste de Friedman foi altamente significativo. A maioria dos híbridos submetidos ao teste de patogenicidade apresentou sintoma de suscetibilidade ao isolado de

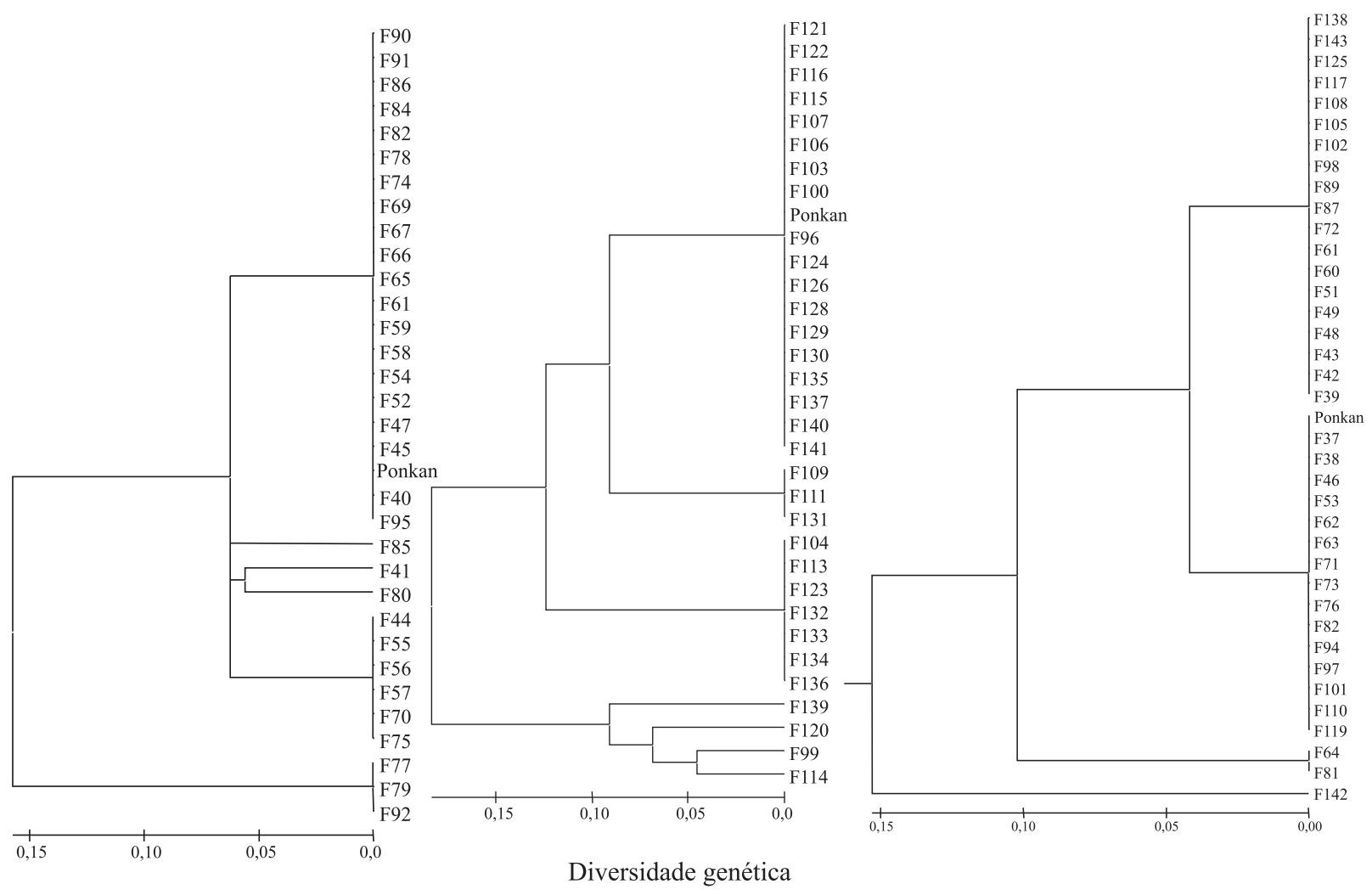

Figura 1. Dendrograma da genitora 'Ponkan' e da progênie $F_{1}$ oriunda da hibridação entre 'Ponkan' x 'Folha Murcha', a partir da análise de Parcimônia e da matriz de distância de Pairwise, baseado no padrão de agrupamento de Neighborjoining. 
Alternaria alternata f. sp. citri testado. Entretanto, houve variação no grau de resistência e suscetibilidade dos híbridos de acordo com as avaliações realizadas aos quatro, sete e dez dias após a inoculação (Tabela 2).

A maioria dos híbridos apresentou sintomas após quatro dias da inoculação e a lesão aumentou de tamanho, até a folha ficar completamente tomada, o que ocorreu dez dias após a inoculação. Apesar de terem apresentado sintomas na primeira avaliação nos híbridos F72 e F139, as lesões não evoluíram mantendo-se constantes ao longo do tempo de avaliação. Os híbridos F57, F99 e F123 apresentaram-se altamente suscetíveis ao fungo.

Nos híbridos F109, F113, F132 e F134, o sintoma só foi observado após sete dias da inoculação. Entre estes, destaca-se o F113, que, embora tenha apresentado sintoma, não se desenvolveu até o final do teste. Quanto

Tabela 2. Teste de patogenicidade realizado em híbridos oriundos da progênie $\mathrm{F}_{1}$ provenientes do cruzamento 'Ponkan' x 'Folha Murcha', que receberam inóculos de isolados de Alternaria alternata f. sp. citri.

\begin{tabular}{|c|c|c|c|c|c|c|}
\hline \multirow[t]{3}{*}{ Híbridos } & \multicolumn{6}{|c|}{ Avaliações (dias após inoculação) } \\
\hline & \multicolumn{2}{|c|}{4} & \multicolumn{2}{|c|}{7} & \multicolumn{2}{|c|}{10} \\
\hline & Mediana & Soma das escalas & Mediana & Soma das escalas & Mediana & Soma das escalas \\
\hline Testemunha & 0 & 24 & 0 & 14 & 0 & 6 \\
\hline F39 & 1,013 & 91,5 & 2,974 & 114 & 2,987 & 81,5 \\
\hline F42 & 1,026 & 92 & 2,908 & 113 & 3 & 97 \\
\hline F43 & 0 & 24 & 0 & 14 & 2,987 & 81,5 \\
\hline F44 & 0 & 24 & 2,974 & 114 & 2,987 & 81,5 \\
\hline F48 & 2,026 & 133 & 2,908 & 113 & 3 & 97 \\
\hline F49 & 1 & 79,5 & 2,026 & 78 & 3 & 97 \\
\hline F55 & 2 & 127,5 & 2,026 & 78 & 3 & 97 \\
\hline F56 & 1 & 79,5 & 2,026 & 78 & 3 & 97 \\
\hline F57 & 2,803 & 144 & 3 & 126,5 & 2,987 & 81,5 \\
\hline F60 & 0,974 & 78,5 & 2 & 74,5 & 2,987 & 81,5 \\
\hline F62 & 1,908 & 115,5 & 3 & 126,5 & 3 & 97 \\
\hline F64 & 0 & 24 & 0 & 14 & 1 & 19,5 \\
\hline F70 & 1 & 79,5 & 2,026 & 79,5 & 3 & 97 \\
\hline F72 & 1,013 & 91,5 & 1 & 38 & 2 & 34,5 \\
\hline F75 & 1 & 79,5 & 2,092 & 88 & 3 & 97 \\
\hline F77 & 1 & 79,5 & 2,066 & 87,5 & 3 & 97 \\
\hline F79 & 1,039 & 91,5 & 1,039 & 47,5 & 3 & 97 \\
\hline F80 & 2 & 127,5 & 3 & 126,5 & 3 & 97 \\
\hline F85 & 1,013 & 91,5 & 2 & 74,5 & 3 & 97 \\
\hline F92 & 1,013 & 91,5 & 3 & 126,5 & 3 & 97 \\
\hline F98 & 1,013 & 91,5 & 2 & 74,5 & 3 & 97 \\
\hline F99 & 3 & 148 & 3 & 126,5 & 3 & 97 \\
\hline F104 & 1,039 & 91,5 & 3 & 126,5 & 3 & 81 \\
\hline F105 & 1,026 & 91 & 2 & 74,5 & 3 & 97 \\
\hline F108 & 0 & 24 & 0 & 14 & 1 & 19,5 \\
\hline F109 & 0 & 24 & 2 & 74,5 & 3 & 97 \\
\hline F111 & 0 & 24 & 0 & 14 & 1 & 19,5 \\
\hline F113 & 0 & 24 & 1 & 38 & 1,066 & 23 \\
\hline F117 & 1,026 & 91 & 1 & 38 & 3 & 97 \\
\hline F123 & 3 & 148 & 3 & 126,5 & 3 & 97 \\
\hline F131 & 0 & 24 & 0 & 14 & 0 & 6 \\
\hline F132 & 0,013 & 36,5 & 2,039 & 87 & 3 & 97 \\
\hline F134 & 0 & 24 & 3 & 126,5 & 3 & 97 \\
\hline F138 & 1,013 & 91,5 & 1,895 & 65 & 3 & 97 \\
\hline F139 & 1,026 & 91 & 1 & 38 & 1 & 19,5 \\
\hline F142 & 1 & 79,5 & 2 & 74,5 & 3 & 97 \\
\hline$S^{(1)}$ & \multicolumn{2}{|c|}{130,68} & \multicolumn{2}{|c|}{131,05} & \multicolumn{2}{|c|}{132,62} \\
\hline GL & \multicolumn{2}{|c|}{37} & \multicolumn{2}{|c|}{37} & \multicolumn{2}{|c|}{37} \\
\hline $\mathrm{P}$ & \multicolumn{2}{|c|}{0,000} & \multicolumn{2}{|r|}{0,000} & \multicolumn{2}{|c|}{0,000} \\
\hline Grande mediana & \multicolumn{2}{|c|}{0,974} & \multicolumn{2}{|r|}{1,895} & \multicolumn{2}{|c|}{2,553} \\
\hline
\end{tabular}

${ }^{(1)}$ Estatística de Friedman ajustada. 
aos híbridos F64, F108 e F111 somente apresentaram leve sintoma após dez dias, com exceção do F43 no qual, após dez dias, a lesão se mostrava muito desenvolvida.

O F131 foi o único, entre os híbridos testados, que não apresentou sintoma em nenhuma das avaliações, mostrando-se potencialmente resistente, nas condições deste trabalho, ao isolado de Alternaria alternata f. sp. citri utilizado.

A variação encontrada no grau de resistência e suscetibilidade à Alternaria alternata f. sp. citri é comum em trabalhos de patogenicidade envolvendo espécies cítricas a este fungo. Vicent et al. (2004), ao avaliar a suscetibilidade de espécies cítricas a Alternaria alternata pv. citri em laboratório, também encontraram variação na suscetibilidade entre as variedades testadas. Gardner et al. (1986) relataram que essa variação é influenciada pelo teste utilizado. Neste trabalho, o teste utilizado seguiu método consagrado em trabalhos conduzidos para testar a resistência de espécies cítricas a Alternaria alternata f. sp. citri (Kohmoto et al., 1991; Solel \& Kimchi, 1997; Peever et al., 1999, 2002; Vicent et al., 2003).

Outros fatores que contribuem para a variação no grau de resistência e suscetibilidade à manchade-alternária das tangerineiras estão relacionados ao tipo de isolado e ao local em que o isolado foi obtido. Entretanto, a confirmação de resistência de variedades de tangerina e híbridos à Alternaria alternata foi verificada em trabalhos anteriores. Kohmoto et al. (1991) verificaram reação de resistência, quando variedades de tangerinas 'King' e seus híbridos 'Encore' e 'Kara-Kara' foram submetidos à inoculação de isolados Aac oriundos da Flórida. Esses autores também observaram comportamento igual na variedade Kara-Kara, quando recebeu inoculo com o isolado Aac, oriundo da Austrália, embora autores como Solel \& Kimchi (1997) tenham verificado que a tangerina 'King' e seus híbridos 'Wilking' e 'Kara-Kara' foram suscetíveis ao isolado Aac, oriundo de Israel. Recentemente, Vicent et al. (2003) observaram a reação de resistência de híbridos 'Ellendalle' e 'Ortanique' oriundos do cruzamento entre $C$. sinensis $\mathrm{x} C$. reticulata, quando foram submetidos à inoculação de três isolados de Alternaria alternata pv. citri, AF 2999-1, AF 3499-1 e AF 5199-2.

\section{Conclusões}

1. Os pares de primers EcoRI AAG - MseI CAG e EcoRI ACC - MseI CAA são os mais eficientes para identificação de híbridos da progênie oriunda do cruzamento 'Ponkan' x 'Folha Murcha'.

2. Os híbridos F64, F108, F111, F113, F131 e F139 são potencialmente resistentes à Alternaria alternata f. sp. citri.

\section{Agradecimentos}

Ao CNPq, à Fapemig e à Fapesp, pelo apoio financeiro.

\section{Referências}

APPLIED BIOSYSTEMS. AFLP Plant Mapping Protocol. Foster City: Perkin Elmer Corporation, 1997. 45p.

BELLA, P.; GUARINO, C.; LA ROSA, R.; CATARA, A. Severe infections of Alternaria spp. on a mandarin hybrid. Journal of Plant Pathology, v.83, p.231, 2001.

CAMERON, J.W.; FROST, H.B. Genetics breeding and nucellar embryony. In: REUTHER, W.; BATCHELOR, L.D.; WEBBER, H.J. (Ed.). The citrus industry volume II: anatomy, physiology, genetics and reproduction. Berkeley: University of California Press, 1968. p.325-370.

CENTRO APTA CITROS SYLVIO MOREIRA. Mancha de alternária das tangerinas. Informativos do Centro de Citricultura, n.3, 2003.

CONAGIN, A.; NAGAI, V.; AMBRÓSIO, L.A. Princípios de técnica experimental e análise estatística de experimentos. Campinas: Instituto Agronômico, 2006. 1 CD-ROM.

CRISTOFANI, M.; MACHADO, M.A. Utilização de marcadores moleculares na identificação de plântulas zigóticas e nucelares em sementeira de limão 'Cravo'. Laranja, v.19, p.147-158, 1998.

CRISTOFANI, M.; NOVELLI, V.; OLIVEIRA, A.C. de; OTAVIANO, A.R.; SOUZA, A.A. de; MACHADO, M.A. Identificação de híbridos de cruzamentos interespecíficos em citros utilizando marcadores RAPD e SSR. Laranja, v.22, p.231-341, 2001.

DOYLE, J.J.; DOYLE, J.L. Isolation of plant DNA from fresh tissue. Focus, v.1, p.13-15, 1991.

FROST, H.B.; SOOST, R.K. Seed reproduction: development of gametes and embryos. In: REUTHER, W.; BATCHELOR, L.D.; WEBBER, H.J. (Ed.). The citrus industry volume II: anatomy, physiology, genetics and reproduction. Berkeley: University of California Press, 1968. p.290-324.

GARDNER, J.M.; KONO, Y.; CHANDLER, J.L. Bioassay and hostselectivity of Alternaria citri toxins affecting rough lemon and mandarins. Physiological and Molecular Plant Pathology, v.29, p.293-304, 1986.

GUO, W.W.; CHENG, Y.J.; CHEN, C.L.; FU, C.H.; DENG, X.X. Molecular characterization of several intergeneric somatic hybrids between Citrus and its related genera. Acta Horticulturae, n.632, p.259-264, 2004. 
HERRERA-ISLA, L. La mancha parda de los cítricos en Cuba. Levante Agrícola, v.31, p.49-50, 1992.

KOHMOTO, K.; AKIMITSU, K.; OTANI, H. Correlation of resistance and susceptibility of citrus to Alternaria alternata with sensitivity to host-specific toxins. Phytopathology, v.81, p.719722, 1991.

KUMAR, S.; TAMURA, K.; NEI, M. MEGA3: integrated software for molecular evolutionary genetics analysis and sequence alignment. Briefings in Bioinformatics, v.5, p.150-163, 2005.

MESTRE, P.F.; ASINS, M.J.; PINA, J.A.; CARBONELL, E.A.; NAVARRO, L. Molecular markers flanking citrus tristeza virus resistance gene from Poncirus trifoliata (L.) Raf. Theoretical and Applied Genetics, v.94, p.458-464, 1997.

MONTENEGRO, H.W.S. Curso avançado de citricultura. Piracicaba: Escola Superior de Agricultura Luiz de Queiroz-USP, 1958. 241p.

MURASHIGE, T.; TUCKER, D.P.H. Growth factor requirement of citrus tissue culture. In: INTERNACIONAL CITRUS SYMPOSIUM, 1., Riverside, 1969. Proceedings. Riverside: University of California Press, 1969. p.1155-1169.

NARVÁEZ, C.R.; VALENZUELA, J.B.; MUNOZ, C.S.; HINRICHSEN, P.R. Comparación de RAPD y AFLP como métodos de identificación genética de vid basad en el estudios de fragmentos genómicos anónimos. Agricultura Técnica, v.60, p.1-20, 2000.

OLIVEIRA, R.P. de; NOVELLI, V.M.; MACHADO, M.A. Freqüência de híbridos em cruzamento entre tangerina 'Cravo' e Laranja 'Pêra': análise de marcadores morfológicos e RAPD. Pesquisa Agropecuária Brasileira, v.35, p.1895-1903, 2000.

PEEVER, T.L.; ALBANEZ, A.; AKIMITSU K.; TIMMER, W. Worldwide phylogeography of the citrus brown spot pathogen, Alternaria alternata. Phytopathology, v.92, p.794-802, 2002.

PEEVER, T.L.; CANIHOS, Y.; OLSEN, L.; ALBANEZ, A.; LIU, Y.C.; TIMMER, W. Population genetic structure and host specificity of Alternaria spp. causing brow spot of Minneola
Tangelo and Rough Lemon in Florida. Phytopathology, v.89, p.851-860, 1999.

PERES, N.A.R.; AGOSTINI, J.P.; TIMMER, L.W. Outbreaks of Alternaria brown spot of citrus in Brazil and Argentina. Plant Disease, v.87, p.750, 2003.

SHIMADA, T.; YAMAMOTO, T.; HIDEAKI, Y.; MASAMI, Y.; YOSHIDA, M.; HAYASHI, T. Application of AFLP to molecular genetic analysis in Peach. Journal of Japan Society Horticulturae Science, v.68, p.67-69, 1998.

SOLEL, Z.; KIMCHI, M. Susceptibility and resistance of citrus genotypes to Alternaria alternata pv. citri. Journal of Phytopathology, v.145, p.389-391, 1997.

SOOST, R.K.; CAMERON, J.W. Citrus. In: JANICK, J.; MOORE, J.N. ( Ed.). Advances in fruit breeding. West Lafayette: Purdue University Press, 1975. p.507-540.

TIMMER, L.W.; SOLEL, Z.; OROZCO SANTOS, M. Alternaria brown spot of mandarin. In: TIMMERS, L.W.; GANSEY, S.M.; GRAHAM, J.H. (Ed.). Compendium of citrus diseases. $2^{\text {nd }} e d$. Minnesota: APS Press, 2000. p.19-20.

VICENT, A.; ARMENGOL, J.; SALES JUNIOR, R.; ALFARO LASSALA, F.; GARCIA JIMENEZ, J. Notas preliminares sobre una necrosis de la mandarina Fortune en la comunidad valenciana. Levante Agrícola, v.349, p.4470-474, 1999.

VICENT, A.; BADAL, M.J.; ASENSI, N.; SANZ, N.; ARMENGOL, J.; GARCÍA-JIMENEZ, J. Laboratory evaluation of citrus cultivars susceptibility and influence of fruit size on Fortune mandarin to infection by Alternaria alternata pv. citri. European Journal of Plant Pathology, v.110, p.245-251, 2003.

VOS, P.; HOGERS, R.; BLEEKER, M.; REIJANS, M.; LEE, T. van de; HORNES, M.; FRIJTERS, A.; POT, J.; PELEMAN, J.; KUIPER, M.; ZABEU, M. AFLP: a new technique for DNA fingerprint. Nucleic Acid Research, v.23, p.4407-4414, 1995.

ZABEAU, M. Selective restriction fragment amplification: a general method for DNA fingerprint. European Patent Application n. 92402629.7. (Publication n. 0534858 A1). 1993. 